\title{
Acute effect of COVID-19 pandemic on urological consultations and urological surgery
}

\author{
COVID-19 pandemisinin ürolojik konsültasyonlara ve ürolojik cerrahiye akut etkisi
}

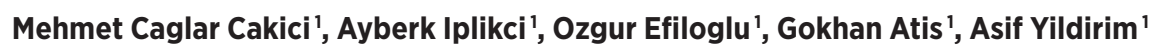

1 Istanbul Medeniyet University School of Medicine, Department of Urology, Istanbul, Turkey

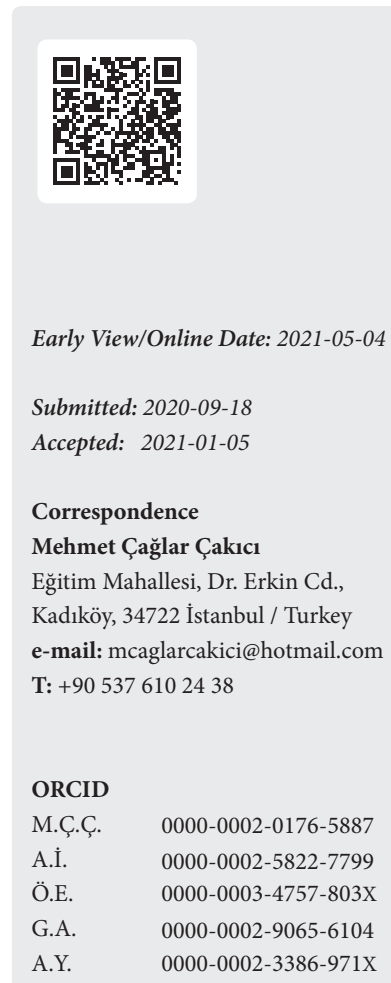

This work is licensed under a Creative Commons Attribution-NonCommercial 4.0 International License.

\section{Özet}

Amaç: Koronavirus hastalığı (COVID-19) üroloji dahil olmak üzere tüm uzmanlık dallarının klinik işleyişlerini büyük ölçüde etkilemiştir. Klinisyenler de bu ani gelişen kaotik süreçten belli oranlarda etkilenmiștir. Bu çalışmada, pandemi döneminin ülkemizdeki akut evresinde ürolojik konsültasyonlara ve ürolojik cerrahiye etkisini değerlendirmeyi amaçladık.

Gereç ve Yöntemler: Hastanemiz lokal etik kurul onayı (22.07.2020 tarihli karar numarası: 2020/0458) alındıktan sonra bu retrospektif çalışma tasarlandı. Ülkemizde görülen ilk vakadan sonraki ilk 4 haftalık periyotta üçüncü basamak sağlık kuruluşu olan hastanemizde Üroloji kliniğine acil servisten ve diğer kliniklerden konsülte edilen hastalar (Grup 1) ile 2019 yılının aynı dönemindeki hastalar (Grup 2) retrospektif olarak tarandı. Hastaların demografik özellikleri, pandemiye özgün triyaj değerlendirmeleri, konsültasyon nedenleri ve sonuçları ayrıntılı olarak analiz edildi.

Bulgular: Toplam 377 hastanın 123'ü $(\% 32,6)$ Grup 1'de, 254'ü $(\% 67,4)$ Grup 2'de idi. Haftalık konsültasyon sayılarında Grup 2'de benzer dağ1lım mevcutken, Grup 1'de ikinci ve üçüncü haftalarda istatistiksel anlamlı düşüş ve dördüncü haftada da artış gözlendi $(\mathrm{p}=0,025)$. Grup l'de konsültasyonların 93'ü $(\% 75,6)$ acil servis hastalaryyken Grup 2'de bu say1 $180(70,9)$ idi $(\mathrm{p}=0,116)$. En sık ilk iki konsültasyon nedeni Grup 1'de üriner enfeksiyonlar ve ürolitiyazisken; Grup 2'de

\section{Abstract}

Objective: Coronavirus disease (COVID-19) has greatly affected the clinical functioning of all sub-specialties, including urology. Clinicians have also been affected by this sudden chaotic process to a certain extent. In this study, we aimed to evaluate the effect of pandemic period on urological consultations and urological surgery in the acute phase of our country.

Material and Methods: This retrospective study was designed after the approval of our hospital's local ethics committee (decision number dated 22.07.2020: 2020/0458) was obtained. In the first 4 weeks after the first case in our country, the data of the patients who were consulted to the Urology clinic from the emergency service and other clinics in our hospital, which is a tertiary healthcare facility (Group 1), and patients in the same period of 2019 (group 2) were retrospectively collected. The demographic characteristics of the patients, specific triage evaluations for the pandemic, reasons for consultation and results were analyzed in detail.

Results: Of the total 377 patients, 123 (32.6\%) were in Group 1, and 254 (67.4\%) were in Group 2. While there was a similar distribution in the number of weekly consultations in group 2, a statistically significant decrease was observed in the second and third weeks in Group 1 and an increase in the fourth week $(p=0.025)$. Ninety-three patients (75.6\%) in Group 1 and 180 patients (70.9\%) in Group 2 were consulted from the emergency service $(p=0.116)$. The two most common reasons for consultation were urinary infections and 
ürolitiyazis ve hematüri idi ( $\mathrm{p}=0,027)$. Grup l'de ürolojik cerrahi müdahale oranı $\% 24,4$ iken; grup 2'de $\% 37,8$ idi ( $\mathrm{p}=0,010)$.

Sonuç: COVID-19 salgınının klinisyenler için zorluğu kendileri ve hastalar için kontaminasyondan korunurken en uygun tedaviyi sağlamak arasında bir denge kurmak olmuştur. Üroloji pratiğinde bu denge, konsültasyonların cerrahi ile sonuçlanması oranında azalma olarak ortaya çıkmıştır.

Anahtar Kelimeler: COVID-19, konsültasyon, koronavirüs, pandemi, ürolojik cerrahi urolithiasis in Group 1; urolithiasis and hematuria in Group 2 ( $\mathrm{p}=$ 0.027 ). While the rate of urological surgical intervention was $24.4 \%$ in Group 1; it was $37.8 \%$ in Group 2 ( $p=0.010$ ).

Conclusion: The difficulty of the COVID-19 outbreak for clinicians has been to strike a balance between providing the most appropriate treatment while avoiding contamination for themselves and their patients. This balance in urology practice has emerged as a decrease in the rate of consultations resulting in surgery.

Keywords: Consultation, coronavirus, COVID-19, pandemic, urological surgery

\section{INTRODUCTION}

In December 2019, a new cause of severe acute respiratory syndrome, coronavirus 2 (SARS-CoV-2), originated in the city of Wuhan, Hubei province, China (1). The disease can manifest itself in a wide range from asymptomatic disease to respiratory failure and death. During the rapid spread of the coronavirus disease (COVID-19) virus worldwide, the World Health Organization (WHO) declared a pandemic on March 11, 2020, the day the first case in our country was detected. As of 31 August 2020, the number of cases worldwide exceeded 25 million and the number of deaths exceeded 800 thousand (2). The number of cases in Turkey was more than 270 thousand, while the number of dead was greater than 6370 (3).

Our hospital provides services to treat both COVID-19 and non-COVID-19 cases as in most hospitals. Clinicians also tried to adapt to the pandemic rapidly in order to provide the most appropriate treatment for all patients during the pandemic, as they are in both a tertiary center and a university hospital. However, clinicians have also been somewhat affected by this sudden chaotic process. In our country, there was a decrease in the number of admissions to hospitals due to both curfew restrictions and patients' postponing their complaints. As a result, treatment services in all specialty areas, including urology, have been severely affected by the pandemic, as seen in most countries (4). In our study, we aimed to evaluate the effect of the pandemic period on urological consultations and urological surgery in the first shock wave of our country.

\section{MATERIAL AND METHODS}

The current descriptive and retrospective clinical study was designed during the initial period of the Covid-19 pandemic after obtaining the permission of the Ministry of Health. Our hospital's local ethics committee approval (date: 22.07.2020 decision number: 2020/0458) was obtained. Between March 23, 2020 and April 19, 2020, which covers the first 4-week period after the first case in our country, patients who were consulted from the emergency room and other clinics to the urology clinic (Group 1) and patients in the same period of 2019 (Group 2) were included in the study. All procedures were performed in accordance with the ethical norms of the local ethics committee and the Helsinki declaration. Patients younger than 18 years were excluded from the study. The demographic characteristics, pandemic-specific triage evaluations, consultation priorities, the reasons and results of the consultation of the patients who were consulted from other clinics and adult emergency service were analyzed in detail in our study.

\section{Statistical Analysis}

Data analysis was performed using the Statistical Package for the Social Sciences version 22 for Windows (SPSS Inc., IBM, NY, USA). One-sample Kolmogorov-Smirnov test was applied to variables with quantitative values. Student $t$ test was used for variables with normal distribution of quantitative data, and Mann-Whitney test was used for others. The ratios of categorical variables were compared using Pearson's chi-square test, and Fisher's exact test was used for data that did not have a normal distribution. Statistical significance level was defined as $\mathrm{p}<0.05$. 


\section{RESULTS}

Of the 377 patients in this study, in which the same period of the last two years was evaluated, 123 (32.6\%) were in Group 1 and 254 (67.4\%) were in Group 2. Age and gender distribution were similar in both groups ( $p>0.05$ ). Weekly distribution in the 4 -week period in Group 2 was similar in the number of consultations. Differently, a statistically significant decrease was observed in the second and third weeks and an increase in the fourth week in group $1(\mathrm{p}=0.025)$. The time frames of the consultations were similar in both groups $(\mathrm{p}=0.860)$ (Table 1$)$. While $93(75.6 \%)$ of the consultations were emergency room patients in Group 1, this number was $180(70.9 \%)$ in Group $2(\mathrm{p}=0.116)$ (Table 2).

When the reasons for consultation were examined, the first two reasons in group 1 were urinary infections and urolithiasis patients. These patients also covered about half (53.6\%) of the total consultations. In group 2 , the two most common reasons for consultation were urolithiasis and hematuria (51.9\% of total consultations) $(p=0,027)$. The rates of urological surgical intervention were $24.4 \%$ vs $37.8 \%$ in group 1 vs group 2 ( $\mathrm{p}=$ 0.010). Although there was an increase in the number of patients receiving behavioral treatment or the number of patients receiving medical treatment, it was not statistically significant $(\mathrm{p}=0.149 ; \mathrm{p}=0.253$, respectively). COVID-19 test was performed for those who had contact history or were symptomatic. COVID-19 test positivity was found in 3 of 123 patients (Table 2). None of the patients died.

Table 1. Distribution of the demographic characteristics of urological consultations by years and the results of the pandemic period.

\begin{tabular}{|c|c|c|c|}
\hline & Group $1(n=123)$ & Group $2(n=254)$ & $P$ value \\
\hline Age, years & $56.1 \pm 22.4$ & $59.3 \pm 22.4$ & 0.195 \\
\hline Gender, n (\%) & & & 0.853 \\
\hline Female & $87(70.7)$ & $182(71.7)$ & \\
\hline Male & $36(29.3)$ & $72(28.3)$ & \\
\hline Number of consultations, $\mathrm{n}(\%)$ & & & 0.025 \\
\hline $1^{\text {st }}$-week & $30(24.4)$ & $63(24.8)$ & \\
\hline $2^{\text {nd }}$-week & $23(18.7)$ & $61(24.0)$ & \\
\hline $3^{\text {rd }}$-week & $23(18.7)$ & $69(27.2)$ & \\
\hline $4^{\text {th }}$-week & $47(38.2)$ & $61(24.0)$ & \\
\hline Time period, hours, n (\%) & & & 0.860 \\
\hline 08:00-20:00 & $82(66.7)$ & $167(65.7)$ & \\
\hline 20:00-08:00 & $41(33.3)$ & $87(34.3)$ & \\
\hline Initial Complaint, n (\%) & & & 0.770 \\
\hline Urological & $88(71.5)$ & $178(70.1)$ & \\
\hline Non-Urological & $35(28.5)$ & $76(29.9)$ & \\
\hline Hospitalization, n (\%) & $20(16.3)$ & $31(12.2)$ & 0.152 \\
\hline \multicolumn{4}{|c|}{ COVID-19 testing status during consultation, $\mathrm{n}(\%)$} \\
\hline Positive & $2(1.6)$ & -- & \\
\hline Processing & $7(5.7)$ & -- & \\
\hline Negative & $5(4.1)$ & -- & \\
\hline Not tested & $109(88.6)$ & $254(100.0)$ & \\
\hline
\end{tabular}


Table 2. Distribution of causes and results of urological consultations by years

\begin{tabular}{|llll|}
\hline & Group 1 (n=123) & Group 2 (n=254) & P value \\
\hline Distribution of Consultations, $\mathrm{n}(\%)$ & & & $0.116^{\mathrm{F}-\mathrm{E}}$ \\
Emergency department - Red zone & $2(1.6)$ & - & \\
Emergency department - Yellow zone & $26(21.1)$ & $60(23.6)$ & \\
Emergency department - Green zone & $65(52.8)$ & $120(47.2)$ & \\
Other clinics & $30(24.4)$ & $74(29.1)$ & \\
\hline Reasons for Consultation , n (\%) & & & 0.027 \\
Hematuria & $20(16.3)$ & $56(22.0)$ & \\
Urinary retention & $6(4.3)$ & $17(6.7)$ & \\
Urinary infection & $34(27.6)$ & $39(15.4)$ & \\
Urolithiasis & $32(26.0)$ & $76(29.9)$ & \\
Catheter dysfunctiyon (Uretral/Nephrostomy) & $4(3.3)$ & $14(5.5)$ & \\
Scrotal pain & $14(11.4)$ & $21(8.3)$ & \\
Lower Urinary Tract Symptoms & $13(10.6)$ & $21(8.3)$ & \\
Diğer Other (Penile edema, etc.) & - & $10(3.9)$ & \\
Treatment, n (\%) & & & \\
Behavioral therapy & $49(39.8)$ & $82(32.3)$ & 0.149 \\
Medical therapy & $44(35.8)$ & $76(29.9)$ & 0.253 \\
Invasive procedure/Surgery & $30(24.4)$ & $96(37.8)$ & 0.010 \\
\hline
\end{tabular}

F-E: Fisher's Exact test

\section{DISCUSSION}

In addition to how urology practice has been affected by the COVID-19 pandemic, efforts to adapt to the management of this process, how health systems are organized globally and what resources are used have gained importance in this pandemic period. Our study reveals important results regarding the impact of the COVID-19 pandemic on urology consultations.

A significant decrease is observed in the number of patients consulted to the urology clinic after the first week of the pandemic period. We found that the consultations decreased to $48.4 \%$ in the four-week period. During the same period, the number of daily admissions to the emergency department of our hospital was approximately 350 , and it was reported that they continued in similar numbers throughout the 4-week period (5). The decrease in the number of urology consultations in the 2nd and 3rd weeks without any major change in the total number of admissions during the pandemic period suggests that non-urgent urological problems are neglected or postponed. It has been previously reported that the number of daily admissions to our emergency department in the same period of 2019 is approximately twice that of the pandemic period (5). A similar rate is seen for urology consultations. Borchert et al. (6) analyzed 53 consultations during the pandemic period and found a $47.5 \%$ decrease in the number of consultations compared to the previous year. Another study that found a remarkable reduction in emergency urological consultations during the COVID-19 pandemic was reported (7). This study was a study comparing 107 consultations over a 36-day period with 266 consultations in the previous year, and it was observed that patients with higher risk admitted to the hospital during the pandemic period. It is thought that time is needed for the clinical results of the patients who delay their admission.

About half of the consultations were non-urgent urological events consulted from the emergency department. Approximately one fourth were consultations from other clinics. There was no statistically significant change in these rates during the pandemic period. However, statistically significant changes were observed in the distribution of the reasons for consul- 
tation. While there was a decrease in the rate of patients consulted for hematuria and urinary catheter problems, the rate of urinary infections increased.

Consultations were divided into 3 groups according to a study examining the reasons for consultation. Standard consultations were completed face-to-face with patients without COVID-19, high-risk consultations were performed face-to-face with patients who were COVID-19 positive or suspected, and consultations, called telemedicine, were completed by telephone interviews for patients with no suspected urologically significant pathology in both patient groups. In these and similar studies in which the reasons for consultation were stratified, it was reported that during the pandemic period, the safety of patients and physicians could be increased by planning a new triage assessment of most urological consultations $(6,8)$. As a matter of fact, we later learned that 1 of the patient consulted was COVID-19 positive in the current study. This makes us think that we need to take some precautions and make changes to protect ourselves. These new approaches clearly demonstrate the impact on health systems, and the use of these approaches has been most frequently reported in Europe $(9,10)$.

Cai et al. (11) evaluated 250 urology consultations completed by phone calls and concluded that it is an appropriate method for relieving patients / improving their quality of life. This method will relieve both national / international healthcare providers and the patient during severe infectious disease periods when we have limited resources $(11,12)$. Borchert et al. (6) reported that the most common cause of consultations during the pandemic period was urinary retention (28.3\%), and hematuria in the previous year. In our study, the most common causes during the pandemic period were urinary infections $(27.6 \%)$ and urolithiasis $(26.0 \%)$. In the previous year, urolithiasis $(29.9 \%)$ and hematuria $(22.0 \%)$ were the first two causes. We thought that two factors played a role in this increase in urinary infections, which had approximately doubled in proportion during the pandemic period. First, the number of admissions may have continued without being affected by the pandemic, as there are often admissions to the emergency department after high fe- ver. As a result of the decrease in the total number of consultations, a proportional increase is expected. Secondly, during the pandemic period, it may be preferred to consult urology clinics instead of infectious diseases clinics that provide maximum health care.

An increase was observed in the behavioral and medical treatment rates applied to the patients, but it was not statistically significant. Similarly, as a result of the consultation, the number of patients who underwent urological surgical intervention decreased statistically significantly by approximately one third. The reason for the difference in treatment and intervention applied to the consulted patients was the decrease in patients who underwent surgical procedures. This shows that the conservative approach is more preferred during the pandemic period. Fortunately, so far, all of our patients tested before emergency or semi-elective surgery have been negative for COVID-19. Still, preventive measures should continue.

Our study has some limitations. The first is that it has a retrospective design. Including data on changes in other specialties during the pandemic period would enrich the study. Its strength is that it is one of the studies with the highest number of patients in the literature in this short period of time. Containing single-center data is one of its strong features.

\section{CONCLUSION}

As a result, it is clear that the COVID-19 outbreak is a difficult period for clinicians in all subspecialities. The challenge has been to establish a balance between preventing contamination and providing optimal treatment for healthcare professionals and patients. This balance in urology practice has emerged as a decrease in the rate of consultations resulting in surgery. Evidence-based strategies are urgently needed to reduce the risk of the spread of COVID-19 or a similar future pandemic.

\section{Conflict of interest}

All authors declare no conflict of interest

\section{Financial Disclosure}

The authors declared that this study has received no financial support. 


\section{Ethical Approval}

The study was approved by the local ethics committee (Approval number: 2020/0458) and written informed consent was received from all participants. The study protocol conformed to the ethical guidelines of the Helsinki Declaration.

\section{REFERENCES}

1. Wang D, Hu B, Hu C, Zhu F, Liu X, Zhang J, et al. Clinical characteristics of 138 hospitalized patients with 2019 Novel coronavirus-infected Pneumonia in Wuhan, China. JAMA. 2020; 323(11):1061-1069.

2. World Health Organization. Coronavirus disease (COVID-19) situation report-162 [online]. 2020 [cited 2021]. Available from https://www.who.int/docs/default-source/coronaviruse/20200630-covid-19-sitrep-162. pdf?sfvrsn=e00a5466_2

3. T.C. Ministry of Health. Turkey daily coronavirus table [online]. 2020 [cited 28 May 2020]. Available from https:// covid19bilgi.saglik.gov.tr/tr/.

4. Chan MC, Yeo SEK, Chong YL, Lee YM. Stepping forward: urologists' efforts during the COVID-19 outbreak in Singapore. Eur Urol. 2020; 78:38-39.

5. Kurtuluş A, Kerem K. Process management and outcomes of the emergency department of a training and research hospital in Turkey during the coronavirus disease 2019 andemic, Anatol Clin. 2020; 25:263-283.
6. Borchert A, Baumgarten L, Dalela D et al. Managing urology consultations during COVID-19 pandemic: application of a structured care pathway. Urology 2020; 141:7-11.

7. Motterle G, Morlacco A, Iafrate $\mathrm{M}$ et al. The impact of COVID-19 pandemic on urological emergencies: a single-center experience. World J Urol. 2020; 23:1-5.

8. Ong LK, Sivaneswaran L, Mohd Najib A et al. Triage of urology referrals and outpatient service during COVID-19 pandemic: experience from a single centre in Malaysia. Med J Malaysia. 2020; 75:400-402.

9. Gravas S, Bolton D, Gomez R et al. Impact of COVID-19 on urology practice: a global perspective and snapshot analysis. J Clin Med. 2020; 9:1730.

10. Diokno AC, Devries JM. The impact of COVID-19 on urologic practice, medical education, and training. Int Urol Nephrol. 2020; 52:1195-1198.

11. Cai T, Verze P, Luciani L et al. What do patients say about telephone-based urological consultations at the time of the COVID-19 pandemic? Minerva Urol Nefrol. 2020; 72:515516.

12. Patel S, Douglas-Moore J. A reflection on an adapted approach from face-to-face to telephone consultations in our urology outpatient department during the COVID-19 pandemic - a pathway for change to future practice?. BJU Int. 2020; 126:339-341. 